\title{
The effects of oligohydramnios on perinatal outcomes after preterm premature rupture of membranes
}

\author{
Subhashini Ladella (iD, David Lee (iD), Fatemeh Abbasi (D), Brian Morgan \\ Department of Obstetrics \& Gynecology, University of California, San Francisco-Fresno, Fresno, CA, USA
}

\begin{abstract}
Objective: Amniotic fluid plays a vital protective role in fetal growth and development. Low amniotic fluid index (AFI) during pregnancy increases risk of adverse perinatal outcomes. Prior studies reported association of oligohydramnios $(\mathrm{AFI}<5 \mathrm{~cm}$ ) with shorter latency period and inconsistent correlation with chorioamnionitis after preterm premature rupture of membranes (PPROM). We studied effects of oligohydramnios on perinatal outcomes after PPROM.

Methods: A retrospective cross-sectional study was performed at our medical center on women with PPROM between 23 to 34 weeks during 2014 to 2016 . The primary predictor variable was AFI of $<5 \mathrm{~cm}$ or $\geq 5 \mathrm{~cm}$ in relationship to perinatal outcomes.

Results: From a total of 117 PPROM cases reviewed, 46 women had AFI $<5 \mathrm{~cm}$ and 71 had AFI $\geq 5 \mathrm{~cm}$. Length of stay (LOS) in neonatal intensive care unit (NICU) was 42 days for $\mathrm{AFI}<5 \mathrm{~cm}$ versus 26.5 days for AFI $>5 \mathrm{~cm}(\mathrm{p}<0.007)$. The mean neonatal Apgar scores at 1 and 5 minutes ( 5.2 and 7.4 respectively) were lower in the $\mathrm{AFI}<5 \mathrm{~cm}$ group compared to $\mathrm{AFI} \geq 5 \mathrm{~cm}(6.9$ at 1 minute and 8.4 at 5 minutes, $\mathrm{p}<0.001$ ).

Conclusion: Oligohydramnios after PPROM is associated with adverse perinatal outcomes such as lower Apgar scores and longer LOS in the NICU. No association was observed with latency period and chorioamnionitis.
\end{abstract}

Keywords: Preterm premature rupture of membranes (PPROM), oligohydramnios, adverse perinatal outcomes, low Apgar scores, NICU length of stay.

\section{Introduction}

Preterm premature rupture of membranes (PPROM), or more recently referred to as preterm prelabor rupture of membranes, is described as rupture of fetal membranes with leakage of amniotic fluid before 37
Özet: Preterm erken membran rüptürü sonrasında oligohidramniyozun perinatal sonuçlar üzerindeki etkileri

Amaç: Amniyotik sıvı, fetal büyüme ve gelişimde önemli bir koruyucu role sahiptir. Gebelik esnasında düşük amniyotik sıvı indeksi (AFI), advers perinatal sonuç riskini artırır. Daha önce yapılan çalışmalar, preterm erken membran rüptürü (PEMR) sonrasında oligohidramniyoz $(\mathrm{AFI}<5 \mathrm{~cm})$ ile daha kısa gecikme dönemi arasında ilişki ve koryoamniyonit ile tutarlı olmayan bir korelasyon bildirmiştir. Çalışmamızda, PEMR sonrasında oligohidramniyozun perinatal sonuçlar üzerindeki etkilerini araştırdık.

Yöntem: Çalışmamız, 2014 ile 2016 yılları arasında gebeliğinin 23 ile 34. haftaları arasında tıbbi merkezimizdeki PEMR'li gebeler üzerinde gerçekleştirilen bir retrospektif kesitsel bir çalışmaydı. Perinatal sonuçlar ile ilişkili olarak primer prediktör değişkeni $<5 \mathrm{~cm}$ veya $\geq 5$ cm'lik AFI idi.

Bulgular: İncelenen toplam 117 PEMR olgusundan 46'sinda AFI $<5 \mathrm{~cm}$ ve 71 'inde $A F I \geq 5 \mathrm{~cm}$ idi. Yenidoğan yoğun bakım ünitesinde (YYBÜ) yatış süresi (YS), AFI $<5 \mathrm{~cm}$ için 42 gün iken, $\mathrm{AFI}>5 \mathrm{~cm}$ için 26.5 gündü $(\mathrm{p}<0.007)$. Ortalama 1. ve 5 . dakika Apgar skorları, $\mathrm{AFI} \geq 5 \mathrm{~cm}$ grubuna (1. dakikada 6.9 ve 5 . dakikada 8.4 ) kiyasla AFI $<5 \mathrm{~cm}$ grubunda (sırasıyla 5.2 ve 7.4$)$ daha düşüktü $(\mathrm{p}<0.001)$.

Sonuç: PEMR sonrası oligohidramniyoz, düşük Apgar skorları ve YYBÜ'de daha uzun kalış süresi gibi advers perinatal sonuçlar ile ilişkilidir. Gecikme dönemi ve koryoamniyonit arasında hiçbir ilişki gözlemlenmemiştir.

Anahtar sözcükler: Preterm erken membran rüptürü (PEMR), oligohidramniyoz, advers perinatal sonuçlar, düşük Apgar skorları, YYBÜ yatış süresi.

weeks of gestation prior to the onset of labor. ${ }^{[1,2}$ PPROM is a serious complication of pregnancy and impacts approximately $3-4 \%$ of pregnancies and is responsible for roughly $30-40 \%$ of preterm births. ${ }^{[3,4]}$ PPROM remains one of the most challenging compli-

Correspondence: Subhashini Ladella, MD. Department of Obstetrics \& Gynecology, University of California, San Francisco-Fresno, Fresno, CA, USA. e-mail: sladella@fresno.ucsf.edu / Received: December 31, 2020; Accepted: January 22, 2021

How to cite this article: Ladella S, Lee D, Abbasi F, Morgan B. The effects of oligohydramnios on perinatal outcomes after preterm premature rupture of membranes. Perinatal Journal 2021;29(1):27-32. doi:10.2399/prn.21.0291005

ORCID ID: S. Ladella 0000-0001-7821-5288; D. Lee 0000-0001-7232-0968; F. Abbasi 0000-0003-2106-5682; B. Morgan 0000-0001-5191-4118 
cations of pregnancy with ongoing debate on formulating optimal management strategies.

Amniotic fluid has a myriad of functions and plays a vital role in fetal growth and lung development. Physically, it protects and prevents the compression of the fetal thorax and umbilical cord. The antimicrobial and bacteriostatic properties of amniotic fluid with its innate immune system components are essential in the prevention of intra-amniotic infection. Loss of amniotic fluid with PPROM results in a significant reduction in these protective properties. ${ }^{[5,6]}$ In addition, the disruption of the membrane seal in PPROM results in microbial invasion of the amniotic cavity causing clinical and histological chorioamnionitis in $30 \%$ and $60 \%$ of PPROM cases. ${ }^{[7,8]}$

Amniotic fluid also serves as a reservoir of fluid and nutrients for the fetus containing proteins, electrolytes, immunoglobulins, and vitamins from the mother. The major pathways involved in amniotic fluid circulation include pulmonary excretion, fetal swallowing, intramembranous movement between fetal blood and the placenta, and trans-membranous movement across the amnion and chorion. In summary, amniotic fluid is a highly dynamic and complex fetal circulation that can be used as a prognosticator of fetal wellbeing. ${ }^{[9,10]}$

Short-term adverse neonatal outcomes following PPROM have been well-described. They include but are not limited to respiratory distress, intraventricular hemorrhage, necrotizing enterocolitis, pulmonary hypoplasia, bronchopulmonary dysplasia, sepsis, and increased risk of fetal and neonatal deaths. Other perinatal complications associated with PPROM include placental abruption, cord accidents, fetal heart rate anomalies, and maternal infectious morbidities. ${ }^{[11,12]}$

Prior studies suggested oligohydramnios or amniotic fluid index (AFI) of less than $<5 \mathrm{~cm}$, in PPROM patients, was associated with decreased latency period and differing AFI measurements $<5 \mathrm{~cm}$ were associated with differing degrees of latency reflecting the impact of residual amniotic fluid levels. ${ }^{[13,14]}$

A limited number of studies have investigated the impact of oligohydramnios on comprehensive perinatal outcomes in patients with PPROM and found an association with certain adverse outcomes such as chorioamnionitis, and subsequent neonatal sepsis.

The purpose of our study was to determine whether there was an association of oligohydramnios after
PPROM with adverse perinatal outcomes resulting in increased maternal or neonatal morbidity.

\section{Methods}

We performed a retrospective cross-sectional study using the electronic health record database at Community Regional Medical Center (CRMC), Fresno, California, USA. Institutional Review Board approval was obtained for this study. Women with a diagnosis of PPROM between 23-34 weeks gestational age who delivered at CRMC from June 2014 to May 2016 were selected for review.

A diagnosis of PPROM was based on a confirmation of one or more of the following criteria: (1) patient's history and physical examination with visualization of gross pooling of fluid in the vagina by sterile speculum examination; (2) a positive nitrazine test; (3) positive fern test; (4) a positive AmniSure ${ }^{\circledR}$ ROM test. Other inclusion criteria for the women with PPROM were those who received antenatal steroids for lung maturity, latency antibiotics, tocolytics, or magnesium sulfate for neuroprotection.

Patients who were excluded from the study comprised of those who presented on admission with chorioamnionitis, placental abruption or non-reassuring fetal status, patients with history of cerclage placement, fetal anomalies, multiple gestations, delivery within 24-48 hours of admission, patients who were at previable gestational age of $<23.0$ weeks, and patients with PPROM $>34.0$ weeks gestational age since induction of labor was recommended for these patients at 34 weeks based on standard-of-care guidelines for PPROM management. ${ }^{[15]}$

Patient health records were reviewed for residual AFI measurements, latency period, the time interval between onset of rupture of membranes and time of delivery, and chorioamnionitis. Diagnoses of chorioamnionitis or intraamniotic infection (IAI), also known as triple I, was reviewed from the electronic medical records (EMR) based on current guidelines. Data abstraction included the documentation of antepartum or intrapartum maternal fever $\left(\geq 38.0^{\circ} \mathrm{C}\right.$ or $100.4^{\circ} \mathrm{F}$ on two occasions 30 minutes apart without another source) and any of following: fetal tachycardia (>160 beats/min for 10 minutes or longer), maternal leukocytosis $\left(1500\right.$ cells $/ \mathrm{mm}^{3}$ in the absence of corticosteroids) and purulent discharge from cervical os. ${ }^{[16]}$ 
Table 1. Perinatal outcomes of PPROM patients associated with residual amniotic fluid volume.

\begin{tabular}{|c|c|c|c|c|}
\hline Perinatal outcomes & AFI category & Mean (Days) & $95 \% \mathrm{Cl}$ & p-value \\
\hline \multirow[t]{2}{*}{ NICU LOS } & $A F \mid<5 \mathrm{~cm}(n=44)$ & 42.0 & $(4.34-26.71)$ & 0.007 \\
\hline & $A F \mid \geq 5 \mathrm{~cm}(n=69)$ & 26.5 & (3.38-27.67) & 0.013 \\
\hline \multirow[t]{2}{*}{ Maternal LOS } & $A F \mid<5 \mathrm{~cm}(n=46)$ & 12.1 & $(-2.14-5.92)$ & 0.356 \\
\hline & $A F \mid \geq 5 \mathrm{~cm}(n=71)$ & 10.1 & $(-2.57-6.35)$ & 0.402 \\
\hline \multirow[t]{2}{*}{ Latency period } & $A F \mid<5 \mathrm{~cm}(\mathrm{n}=46)$ & 10.8 & $(-4.16-4.98)$ & 0.859 \\
\hline & $A F \mid \geq 5 \mathrm{~cm}(\mathrm{n}=71)$ & 10.4 & $(-4.35-5.18)$ & 0.864 \\
\hline
\end{tabular}

AFI: amniotic fluid index; LOS: length of stay; NICU: neonatal intensive care unit; PPROM: preterm premature rupture of membranes.

Neonatal Apgar scores and disposition, including admission to the neonatal intensive care unit (NICU) were reviewed as well.

In our study, we divided PPROM patients into two groups based on AFI measurement at time of admission: patients with AFI less than $<5 \mathrm{~cm}$ and patients with $\mathrm{AFI} \geq 5 \mathrm{~cm}$. Data abstracted was compared for maternal age, gestational age at admission, gestational age at delivery, latency period, chorioamnionitis, route of delivery, birthweight, Apgar scores at 1 and 5 minutes, NICU length of stay, and neonatal complications.

In addition, perinatal characteristics and outcomes for these two groups of PPROM patients, those with residual $\mathrm{AFI}<5 \mathrm{~cm}$ and those with $\mathrm{AFI} \geq 5 \mathrm{~cm}$ was also compared.

\section{Statistical analysis}

Data extracted from the hospital electronic record database was analyzed with SPSS. Bivariate analysis with two-tailed t-tests was performed with an $\alpha=0.05$ as the threshold for significance.

\section{Results}

A total of 117 PPROM cases were reviewed. Patients were categorized into two groups based on the residual $\mathrm{AFI}<5.0 \mathrm{~cm}$ and $\mathrm{AFI} \geq 5 \mathrm{~cm}$ at admission (Table 1). All patients were delivered either upon onset of spontaneous labor or upon reaching 34 weeks gestational age, whichever occurred earliest. In cases of infection or non-reassuring fetal status, patients were delivered earlier.

Patients with post-PPROM AFI $<5 \mathrm{~cm}$ delivered neonates who required a significantly longer NICU length of stay (LOS) than those with $\mathrm{AFI} \geq 5 \mathrm{~cm}$ (Table 1).
In contrast, those with $\mathrm{AFI}<5 \mathrm{~cm}$ and $\mathrm{AFI} \geq 5 \mathrm{~cm}$, did not show a significant difference in the average maternal inpatient LOS which was comparable at 12.1 and 10.1 days, respectively, between the two groups. The average latency period was also similar between the two groups at 10.8 days and 10.4 days, respectively.

Chi-squared analysis showed no statistically significant association between chorioamnionitis and the two comparison groups of the PPROM patients (Table 2).

Data of the interventions used in the inpatient management of these patients with PPROM and their route of delivery was also collected. A majority of patients successfully achieved a vaginal delivery. The overall neonatal survival rate was at $98.3 \%$ (Fig. 1).

The immediate post-birth performance of the neonates delivered was reviewed which demonstrated lower Apgar scores at both 1 minute and 5 minutes born to mothers in the group with low residual amniotic fluid index $<5 \mathrm{~cm}$ when compared to the group with residual amniotic fluid index of $\geq 5 \mathrm{~cm}$ (Table 3).

The average interval from day of admission to the hospital to the delivery date for the PPROM patients was 10.7 days and the mean gestational age at time of delivery was 31 weeks (Table 4).

Data abstraction for NICU length of stay and neonatal Apgar scores could be assessed for 113 PPROM

Table 2. Diagnosis of chorioamnionitis.

\begin{tabular}{lccc} 
& \multicolumn{2}{c}{ AFI category $(\mathbf{N}=\mathbf{1 1 7})$} & \\
\cline { 2 - 3 } Chorioamnionitis & $\begin{array}{c}\text { AFI<5 cm } \\
(\mathbf{n}=\mathbf{4 6})\end{array}$ & $\begin{array}{c}\mathbf{A F l} \geq \mathbf{5} \mathbf{~ c m} \\
(\mathbf{n}=\mathbf{7 1})\end{array}$ & p-value \\
Yes & 10 & 12 & 0.69 \\
No & 36 & 59 & 0.06 \\
\hline
\end{tabular}

AFI: amniotic fluid index. 
Table 3. Neonatal Apgar scores and association with AFI.

\begin{tabular}{|c|c|c|c|c|}
\hline \multirow[b]{2}{*}{ AFI category } & \multicolumn{2}{|c|}{ Apgar at $1 \mathrm{~min}$} & \multicolumn{2}{|c|}{ Apgar at $5 \mathrm{~min}$} \\
\hline & Mean & SD & Mean & SD \\
\hline$A F I<5 \mathrm{~cm}(n=46)$ & 5.2 & 3 & 7.4 & 2.1 \\
\hline$A F I \geq 5 \mathrm{~cm}(n=71)$ & 6.9 & 1.9 & 8.4 & 0.9 \\
\hline p-value & $<0.01$ & & $<0.01$ & \\
\hline
\end{tabular}

t-tests for independent samples were conducted to detect differences in APGAR scores at 1 and 5 minutes. AFI: amniotic fluid index.

patients and 100 PPROM patients respectively, due to gaps in EMR documentation with information lacking for these variables in some patients.

\section{Discussion}

PPROM remains a significant obstetrical complication of pregnancy with high rates of perinatal morbidity and mortality. However, existing data on the association of $\mathrm{AFI}$ as one of the prognosticators of perinatal and neonatal outcomes has some contradictory results. Therefore,
Table 4. Maternal and neonatal clinical characteristics with PPROM.

\begin{tabular}{lcc} 
Characteristics & Mean & Median \\
\hline Maternal age (years) & 29.1 & 30.0 \\
AFI at PPROM (cm³) & 6.7 & 5.9 \\
GA at PPROM (weeks) & 29.7 & 31.2 \\
GA at delivery (weeks) & 31.0 & 32.1 \\
Latency period (days) & 10.5 & 6.0 \\
PPROM admission LOS (days) & 10.7 & 7.0 \\
NICU LOS (days) & 32.5 & 23.0 \\
\hline
\end{tabular}

AFI: amniotic fluid index; GA: gestational age; LOS: length of stay; NICU: neonatal intensive care unit; PPROM: preterm premature rupture of membranes.

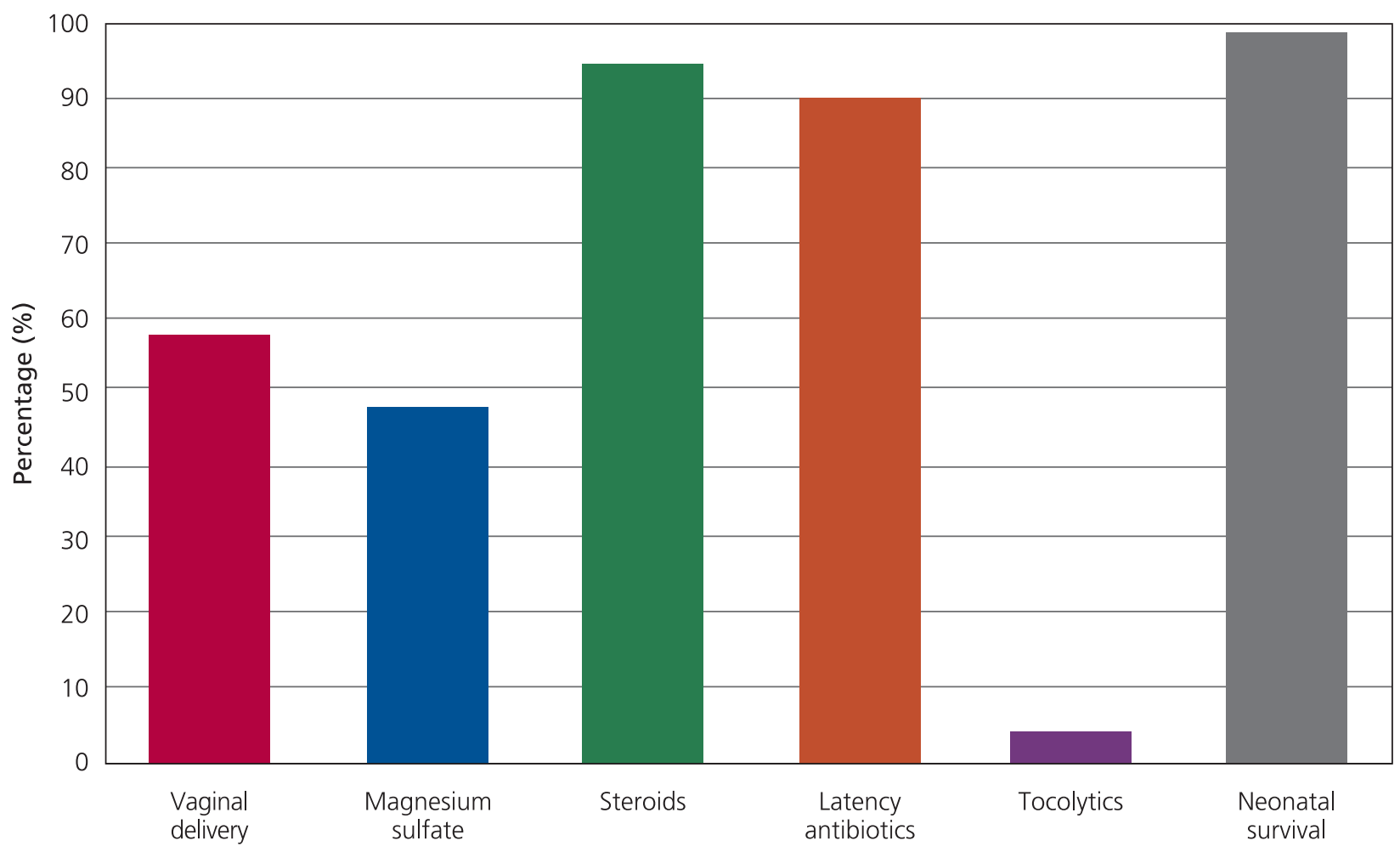

Fig. 1. Frequencies of perinatal interventions and outcomes. 
our study was planned to evaluate the correlation of residual AFI following PPROM with perinatal outcomes among patients expectantly managed after a diagnosis of PPROM.

In our study, we found significant differences in the neonatal outcomes including greater NICU length of stay and lower Apgar scores at 1 and 5 mins respectively in the oligohydramnios group $(\mathrm{AFI}<5 \mathrm{~cm}$ ) compared to the normal amniotic fluid volume group of patients $(\mathrm{AFI} \geq 5 \mathrm{~cm})$. There were no significant differences in the maternal complications including chorioamnionitis, latency period, maternal length of stay and rates of cesarean deliveries between the two comparison groups of $\mathrm{AFI}<5 \mathrm{~cm}$ and $\mathrm{AFI} \geq 5 \mathrm{~cm}$.

Prior studies such as Tavassoli et al. observed a shorter latency period for PPROM patients with $\mathrm{AFI}<5$ $\mathrm{cm}{ }^{[17-19]}$ In addition, studies by Vintzileos et al. and Gonik et al. previously implicated oligohydramnios in patients with PPROM as a significant risk factor for perinatal infection. ${ }^{[20,21]}$ Of note, we did not categorize the latency period outcomes for the PPROM patients by further subdividing the two groups $(<5 \mathrm{~cm}$ and $\geq 5 \mathrm{~cm})$ based on gestational age sub-categories from 23 weeks to 34 weeks gestation. As a result, the latency periods may have been falsely shortened if a patient was admitted closer to 34.0 weeks gestational age and thus may have influenced the lack of significant association with the oligohydramnios group of PPROM patients.

Other studies also showed contradicting findings regarding association of oligohydramnios with neonatal sepsis and adverse outcomes with PPROM. For instance, Vermillion et al. showed an association between AFI $<5$ $\mathrm{cm}$ and early neonatal sepsis. However, Borna et al. did not demonstrate this association though it was limited in its ability to establish the diagnosis of early neonatal sepsis. ${ }^{[1,22]}$ Due to inadequate culturing techniques, studies such as Gonik et al. and Mercer et al. also did not find a relation between oligohydramnios after PPROM and neonatal infections. ${ }^{[21,23]}$

We found an association between $\mathrm{AFI}<5 \mathrm{~cm}$ and adverse neonatal outcomes including lower Apgar scores and increased length of stay in the NICU. We could not demonstrate any correlation between $\mathrm{AFI}<5 \mathrm{~cm}$ and chorioamnionitis or latency period. This lack of association that was observed may have been limited by a smaller sample size and potentially limited power.
Further research would be helpful in elucidating the effects of residual AFI on perinatal morbidities with a larger sample size and assessing the correlation of perinatal outcomes based gestational age categories.

\section{Conclusion}

In conclusion, in our study, we found that low residual amniotic fluid levels with a diagnosis of oligohydramnios in PPROM patients contributes to adverse neonatal outcomes. Our data demonstrates that initial amniotic fluid assessment of patients with PPROM is a predictor of adverse neonatal outcomes. The residual AFI can be used as an important prognostic factor for determining perinatal outcomes in PPROM patients and help direct the care counseling and management approaches for the PPROM patients especially, when PPROM occurs at very preterm gestational age.

Funding: This work did not receive any specific grant from funding agencies in the public, commercial, or not-for-profit sectors.

Compliance with Ethical Standards: The authors stated that the standards regarding research and publication ethics, the Personal Data Protection Law and the copyright regulations applicable to intellectual and artistic works are complied with and there is no conflict of interest.

\section{References}

1. American College of Obstetricians and Gynecologists' Committee on Practice Bulletins-Obstetrics. Prelabor rupture of membranes: ACOG Practice Bulletin, Number 217. Obstet Gynecol 2020;135:e80-e97. [PubMed] [CrossRef]

2. Martins JG. Maternal and perinatal outcomes in pregnancies after preterm premature rupture of membranes determined by single deepest vertical pocket. Obstet Gynecol Int J 2017;6:610. [CrossRef]

3. Mercer BM. Preterm premature rupture of the membranes. Obstet Gynecol 2003;101:178-93. [PubMed] [CrossRef]

4. Ananth C V, Joseph KS, Oyelese Y, Demissie K, Vintzileos AM. Trends in preterm birth and perinatal mortality among singletons: United States, 1989 through 2000. Obstet Gynecol 2005;10:1084-91. [PubMed] [CrossRef]

5. Para R, Romero R, Miller D, Panaitescu B, Varrey A, Chaiworapongsa $T$, et al. Human $\beta$-defensin-3 participates in intra-amniotic host defense in women with labor at term, spontaneous preterm labor and intact membranes, and preterm prelabor rupture of membranes. J Matern Fetal Neonatal Med 2020;33:4117-32. [PubMed] [CrossRef]

6. Mao Y, Pierce J, Singh-Varma A, Boyer M, Kohn J, Reems JA. Processed human amniotic fluid retains its antibacterial activity. J Transl Med 2019;17:68. [PubMed] [CrossRef] 
7. Kacerovsky M, Musilova I, Khatibi A, Skogstrand K, Hougaard $\mathrm{D}$, Tambor $\mathrm{V}$, et al. Intraamniotic inflammatory response to bacteria: analysis of multiple amniotic fluid proteins in women with preterm prelabor rupture of membranes. J Matern Fetal Neonatal Med 2012;25:2014-9. [PubMed] [CrossRef]

8. Cobo T, Kacerovsky M, Palacio M, Hornychova H, Hougaard DM, Skogstrand K, et al. A prediction model of histological chorioamnionitis and funisitis in preterm prelabor rupture of membranes: analyses of multiple proteins in the amniotic fluid. J Matern Fetal Neonatal Med 2012;25:1995-2001. [PubMed] [CrossRef]

9. Dubil EA, Magann EF. Amniotic fluid as a vital sign for fetal wellbeing. Australas J Ultrasound Med 2013;16:62-70. [PubMed] [CrossRef]

10. Fitzsimmons ED, Bajaj T. Embryology, amniotic fluid.; 2020. In: StatPearls [Internet]. Treasure Island, FL: StatPearls Publishing; 2020 Jan. [PubMed]

11. Roberts CL, Wagland P, Torvaldsen S, Bowen JR, Bentley JP, Morris JM. Childhood outcomes following preterm prelabor rupture of the membranes (PPROM): a population-based record linkage cohort study. J Perinatol 2017;37:1230-5. [PubMed] [CrossRef]

12. Drassinower D, Friedman AM, Obiãan SG, Levin H, GyamfiBannerman C. Prolonged latency of preterm prelabour rupture of membranes and neurodevelopmental outcomes: a secondary analysis. BJOG 2016;123:1629-35. [PubMed] [CrossRef]

13. Coolen J, Kabayashi K, Wong K, Mayes DC, Bott N, Demianczuk N. Influence of oligohydramnios on preterm premature rupture of the membranes at 30 to 36 weeks' gestation. J Obstet Gynaecol Can 2010;32:1030-4. [PubMed] [CrossRef]

14. Storness-Bliss C, Metcalfe A, Simrose R, Wilson RD, Cooper SL. Correlation of residual amniotic fluid and perinatal outcomes in periviable preterm premature rupture of membranes. J Obstet Gynaecol Can 2012;34(2):154-8. [PubMed] [CrossRef]

15. American College of Obstetricians and Gynecologists' Committee on Practice Bulletins-Obstetrics. Practice Bulletin
No. 171: Management of preterm labor. Obstet Gynecol 2016; 128(4):e155-64. [PubMed] [CrossRef]

16. Higgins RD, Saade G, Polin RA, Grobman WA, Buhimschi IA, Watterberg $\mathrm{K}$, et al. Evaluation and management of women and newborns with a maternal diagnosis of chorioamnionitis: summary of a workshop. Obstet Gynecol 2016;127: 426-36. [PubMed] [CrossRef]

17. Tavassoli F, Ghasemi M, Mohamadzade A, Sharifian J. Survey of pregnancy outcome in preterm premature rupture of membranes with amniotic fluid index $<5$ and $\geq 5$. Oman Med J 2010; 25:118-23. [PubMed] [CrossRef]

18. Park JS, Yoon BH, Romero R, Moon JB, Oh SY, Kim JC, et al. The relationship between oligohydramnios and the onset of preterm labor in preterm premature rupture of membranes. Am J Obstet Gynecol 2001;184:459-62. [PubMed] [CrossRef]

19. Vermillion ST, Kooba AM, Soper DE. Amniotic fluid index values after preterm premature rupture of the membranes and subsequent perinatal infection. Am J Obstet Gynecol 2000; 183:271-6. [PubMed] [CrossRef]

20. Vintzileos AM, Campbell WA, Nochimson DJ, Weinbaum PJ. Degree of oligohydramnios and pregnancy outcome in patients with premature rupture of the membranes. Obstet Gynecol 1985;66:162-7. [PubMed]

21. Gonik B, Bottoms SF, Cotton DB. Amniotic fluid volume as a risk factor in preterm premature rupture of the membranes. Obstet Gynecol 1985;65:456-9. [PubMed]

22. Borna S, Borna H, Khazardoost S, Hantoushzadeh S. Perinatal outcome in preterm premature rupture of membranes with Amniotic fluid index < 5 (AFI < 5). BMC Pregnancy Childbirth 2004;4:15. [PubMed] [CrossRef]

23. Mercer BM, Rabello YA, Thurnau GR, Miodovnik M, Goldenberg RL, Das AF, et al.; NICHD-MFMU Network. The NICHD-MFMU antibiotic treatment of preterm PROM study: impact of initial amniotic fluid volume on pregnancy outcome. Am J Obstet Gynecol 2006;194:438-45. [PubMed] [CrossRef] 